\section{Erratum}

https://doi.org/10.11646/zootaxa.5032.4.9

http://zoobank.org/urn:lsid:zoobank.org:pub:BE7E5E14-352C-4EB6-A8FF-3B7F88BCF9A2

\title{
STEPHANY ARIZALA, FACUNDO MARTÍN LABARQUE \& DANIELE POLOTOW (2021) Revision of the Neotropical spider genus Acanthoctenus (Araneae: Ctenidae: Acanthocteninae). Zootaxa, 4920: 001-055.
}

On page 5, the legend of Figure 4 is incorrect. The holotype deposited in UFMG 22307 was collected in Rio Tuichui, Parque Nacional Madidi, Franz Tamayo, La Paz, Bolivia and the photos were taken by Arthur Anker \& Pedro H. Martins.

On page 13, Figure 10B, the distribution of Acanthoctenus torotoro Arizala, Labarque \& Polotow, 2021 is incorrect. The correct figure is presented below.

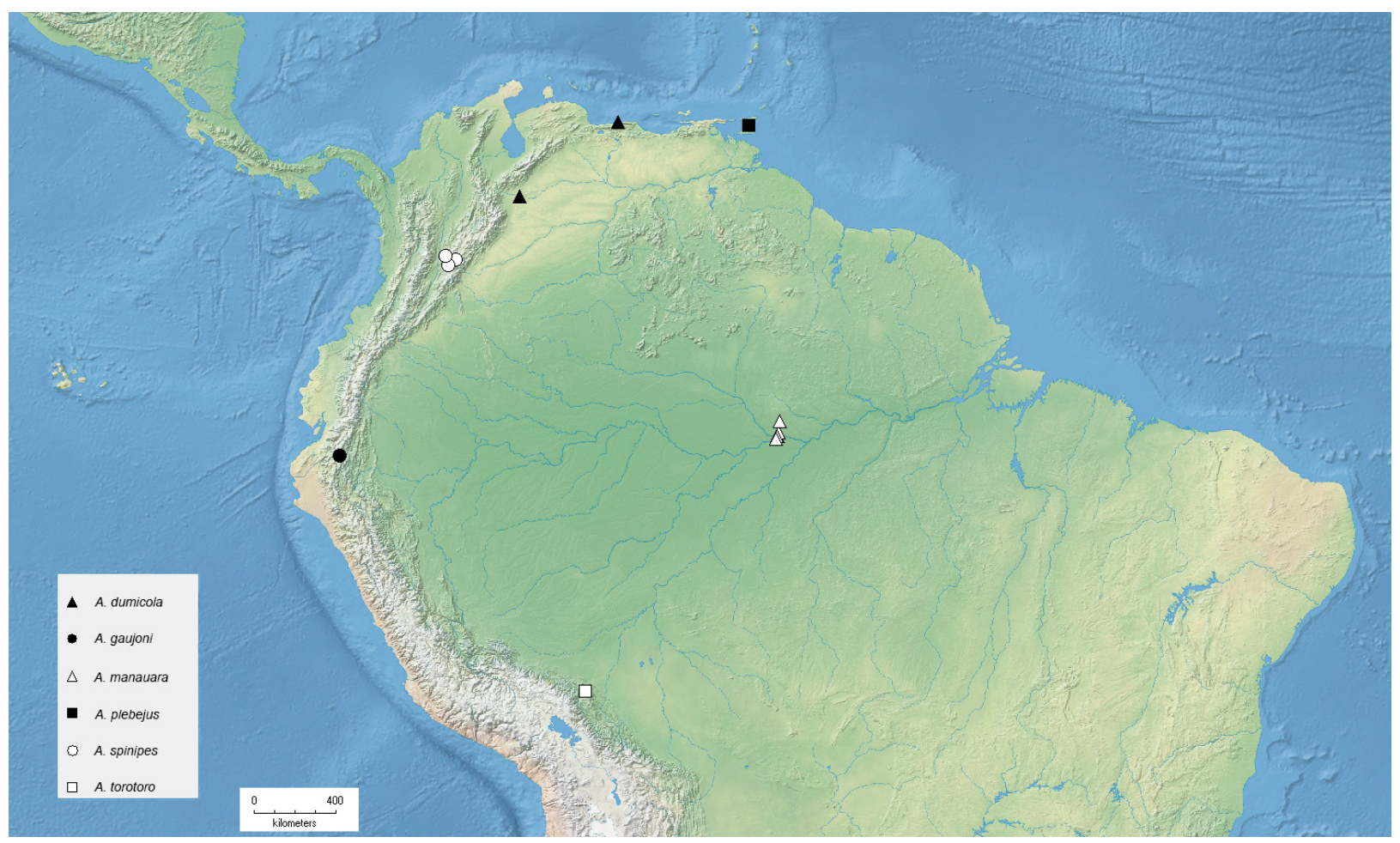

Figure 10B. Distribution map of Acanthoctenus species, north of South America.

On Page 37, the citation of Lehtinen 1967, figure 420 is incorrect and should be removed. The figure shows the male of Acanthocenus spiniger Keyserling, 1877.

On page 50, the collection data of the type material of Acanthoctenus torotoro Arizala, Labarque \& Polotow, 2021 is incorrect. The male holotype was collected in Rio Tuichui, Parque Nacional Madidi, 14¹4'40.3"S, 68²1'35.4”'W, Franz Tamayo, La Paz, Bolivia, 19-21.VII.2017. Information on collectors and collection number are correct. 